\title{
THE ROLE OF EXTRACELLULAR CALCIUM IN THE SECRETORY RESPONSE OF THE EXOCRINE PANCREAS TO SECRETIN AND FORSKOLIN
}

\author{
Tomoko Yoshida and Tomio KanNo \\ Department of Physiology, Faculty of Veterinary Medicine, Hokkaido University, Sapporo 060, Japan
}

\begin{abstract}
The influence of extracellular $\mathrm{Ca}^{2+}$ on secretin-induced secretory responses (enzyme output and juice flow) was examined in the isolated perfused rat pancreas. Secretin in the range of $100 \mathrm{pM}$ to $10 \mathrm{nM}$ produced dose-dependent secretory responses. The secretin-induced enzyme output was markedly inhibited when $\mathrm{CaCl}_{2}$ was removed from the perfusing solution, whereas the juice flow by secretin at higher concentrations (1.0 and $10 \mathrm{nM})$ was not significantly inhibited. Not only the enzyme output but also the juice flow induced by $1 \mu \mathrm{M}$ forskolin were inhibited in the $\mathrm{Ca}^{2+}$-deficient environment. Continuous stimulation with $100 \mu \mathrm{M}$ dibutyryl cAMP caused a gradual increase in the pancreatic secretory responses. The enzyme output was abolished but the juice flow was slightly inhibited in the $\mathrm{Ca}^{2+}$-deficient environment. Continuous stimulation with $1 \mathrm{nM}$ secretin induced a gradual increase in the amount of intracellular cyclic AMP, which was significantly decreased in the $\mathrm{Ca}^{2+}$-deficient environment. The present results show that pancreatic enzyme output induced by secretin depends on the extracellular $\mathrm{Ca}^{2+}$ concentration. Two possible mechanisms involved in the $\mathrm{Ca}^{2+}$-dependent enzyme output were discussed in relation to the two kinds of intracellular second messengers, $\mathrm{Ca}^{2+}$ and cyclic AMP.
\end{abstract}

The following views have been admitted to explain exocrine secretion of the pancres, although the experimental basis for these has not been fully established (3). 1) The exocrine pancreas consists of two functional units: acinar cells, which secrete digestive enzymes and zymogens, and entro-acinar and terminal duct cells, which are responsible for electrolyte secretion; 2) secretin acts only on terminal duct cells and centro-acinar cells to stimulate an isotonic secretion rich in bicarbonate; and 3) cholecystokinin-pancreozymin (CCK) and acetylcholine act on acinar cells to cause the extrusion of the contents of zymogen granules by exocytosis. In the rabbit pancreas, Schulz, Yamagata and Weske (19) concluded that the entire ductular system is involved in electro- lyte secretion induced by secretin, and the conclusion was supported principally by Swanson and Solomon (24) with the distinction that the latter considered the largest extralobular ducts to lack secretory capacity. These views have also been supported by experimental results from the cat pancreas $(5$, $3)$. In the rat pancreas, however, it has been shown that CCK and caerulein strongly stimulate not only the rate of enzyme output but also the rate of flow of pancreatic juice $(9,10$, $12,21)$. In isolated acinar cell preparation of the rat, De Pont et al. (7) have shown that CCK stimulates pancreatic enzyme output not only by increasing the cytosolic concentration of $\mathrm{Ca}^{2+},\left[\mathrm{Ca}^{2+}\right]_{\mathrm{c}}$, but also by activating adenylate cyclase to increase cytosolic cyclic AMP 
concentration. They have also shown that secretin activates adenylate cyclase and induces pancreatic enzyme output. To elucidate the possible influence of extracellular $\mathrm{Ca}^{2+}$, the isolated perfused preparation of rat pancreas may provide a promising clue: the perfusion tehcnique has been used successfully in simultaneous measurements of the pancreatic enzyme release and juice flow in the environment containing various $\mathrm{Ca}^{2+}$ concentrations $(13,14)$. The results of the present study show that secretin, forskolin and dibutyryl adenosine $3^{\prime}, 5^{\prime}$-cyclic monophosphate (dbcAMP) produce a marked increase in both pancreatic protein output and fluid secretion, and that the protein output response is abolished but the fluid secretion response is only partially inhibited in the $\mathrm{Ca}^{2+}$-deficient environment.

\section{MATERIALS AND METHODS}

Male Sprague-Dawley strain rats (about $200 \mathrm{~g}$ ) were fasted but allowed water for $24 \mathrm{~h}$ before the start of each experiment. The isolated perfused pancreas was prepared as reported previously (14). Briefly, under ether anesthesia, the vascular system was cannulated and perfused through the superior mesentric and coeliac arteries, with the portal vein as outlet. The rate of vascular perfusion was kept constant at $2 \mathrm{ml} / \mathrm{min}$ by a roller pump. The hepatic end of the duct was ligated and the pancreatic juice was collected from the duodenal end following cannulation with a stainless steel tube.

The composition of the standard KrebsHenseleit solution used for perfusing and bathing the preparation was as follows (mM): $\mathrm{NaCl}, 131 ; \mathrm{KCl}, 5.6 ; \mathrm{CaCl}_{2}, 2.5 ; \mathrm{MgCl}_{2}, 1$; $\mathrm{NaHCO}_{3}, 25$; HEPES ( $N$-2-hydroxyethyl piperazine- $N^{\prime}$-2-ethane sulfonic acid; Sigma, St. Louis), 1 ; glucose 5. In the $\mathrm{Ca}^{2+}$-deficient solution, $\mathrm{CaCl}_{2}$ was omitted. Dextran T-70 (Meito, Nagoya) was added to the perfusing solution at a final concentration of $5 \%(\mathrm{w} / \mathrm{v})$. The solution was equilibrated with $5 \% \mathrm{CO}_{2}$ in $\mathrm{O}_{2}$ and had a $\mathrm{pH}$ of 7.4. Pure natural porcine secretin $(3,500 \mathrm{U} / \mathrm{mg}$, by the courtesy of Professor V. Mutt, Karolinska Institute, Stockholm), forskolin (Calbiochem, La Jolla) and dbcAMP (Sigma, St. Louis) were added to the perfusing solution. dbcAMP was used with IBMX (isobutyl-methyl-xanthine; Calbiochem, La Jolla) to assure the effectiveness of dbcAMP.
Pancreatic protein output and juice flow were estimated as reported previously (13). Content of cyclic AMP was estimated as reported by Brown et al. (2) with the aid of an assay kit for cyclic AMP (Amersham, England). Results are expressed as the mean $\pm S E$ of several experiments, and are analyzed by Student's $t$-test.

\section{RESULTS}

\section{Influence of $\mathrm{Ca}^{2+}$-Removal on Secretory Responses Induced by Secretin}

The isolated pancreas was perfused first with standard solution for 15 min to reach steady levels, after which the resting levels of secretory responses (pancreatic juice flow and protein output) were estimated. The pancreas was then stimulated continuously by perfusing it with secretin. Continuous stimulation with secretin at 0.1 or $0.2 \mathrm{nM}$ induced a gradual increase in juice flow and a transient rise in protein output (Fig. 1). The secretin-induced juice flow increased gradually to reach a plateau level of several times greater than the corresponding resting level $20 \mathrm{~min}$ after starting the continuous stimulation, maintained the plateau level during the continuous stimulation and then gradually decreased toward the resting level after termination of the stimulation. The secretin-induced protein output, however, increased transiently to about three times greater than the resting level $10 \mathrm{~min}$ after starting the continuous stimulation followed by a gradual decrease to the resting level during the stimulation.

The protein output and the juice flow in response to the continuous stimulation with 1 or $10 \mathrm{nM}$ secretin gradually reached the plateau levels, which were maintained as long as the stimulation was continued (Fig. 1).

When $\mathrm{Ca}^{2+}$ was removed from the perfusing and bathing solution, the protein output induced by continuous stimulation with 0.1 , $0.2,1$ or $10 \mathrm{nM}$ secretin was strongly inhibited (Fig. 2). The juice flow induced by the stimulation with $0.1,0.2,1$ or $10 \mathrm{nM}$ secretin, however, was only partly inhibited in the $\mathrm{Ca}^{2+}$ deficient environment. The levels of the plateau phase of juice flow induced by stimulation with $0.1,0.2,1$, and $10 \mathrm{nM}$ secretin in the $\mathrm{Ca}^{2+}$-deficient environment were about 54,54 , 81 , and $76 \%$ of the corresponding levels recorded in the $\mathrm{Ca}^{2+}$-sufficient environment.

To examine further the influence of extracellular $\mathrm{Ca}^{2+}$, secretin-induced protein output 

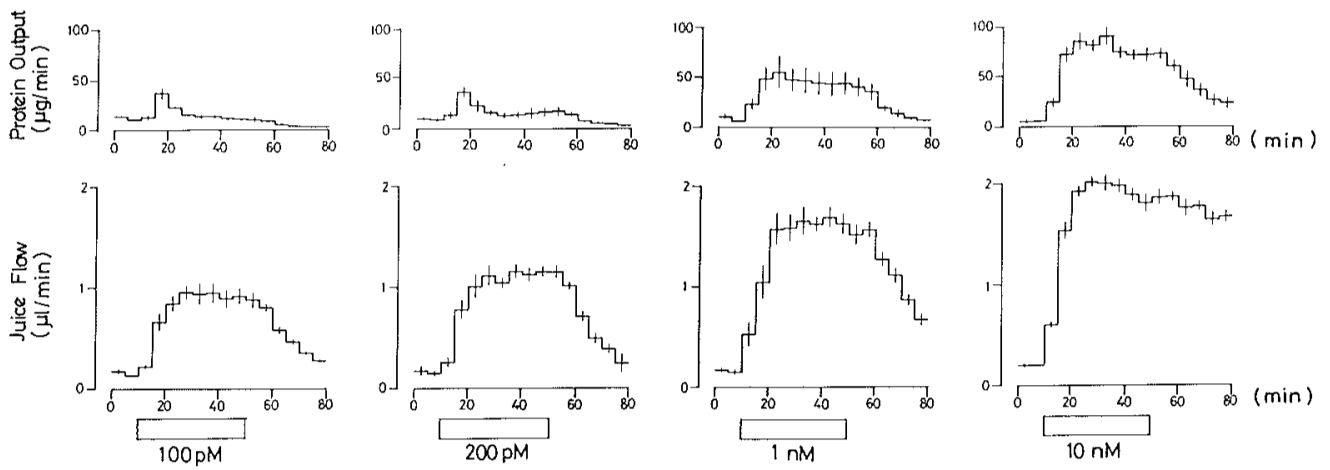

Fig. 1 Time course of changes in pancreatic protein output and juice flow during continuous stimulation of the isolated rat pancreas with $0.1,0.2,1$ and $10 \mathrm{nM}$ secretin in a standard solution containing $2.5 \mathrm{mM}$ $\mathrm{Ca}^{2+}$. Each value represents the mean of four experiments. The open horizontal bar indicates the period of secretin stimulation.
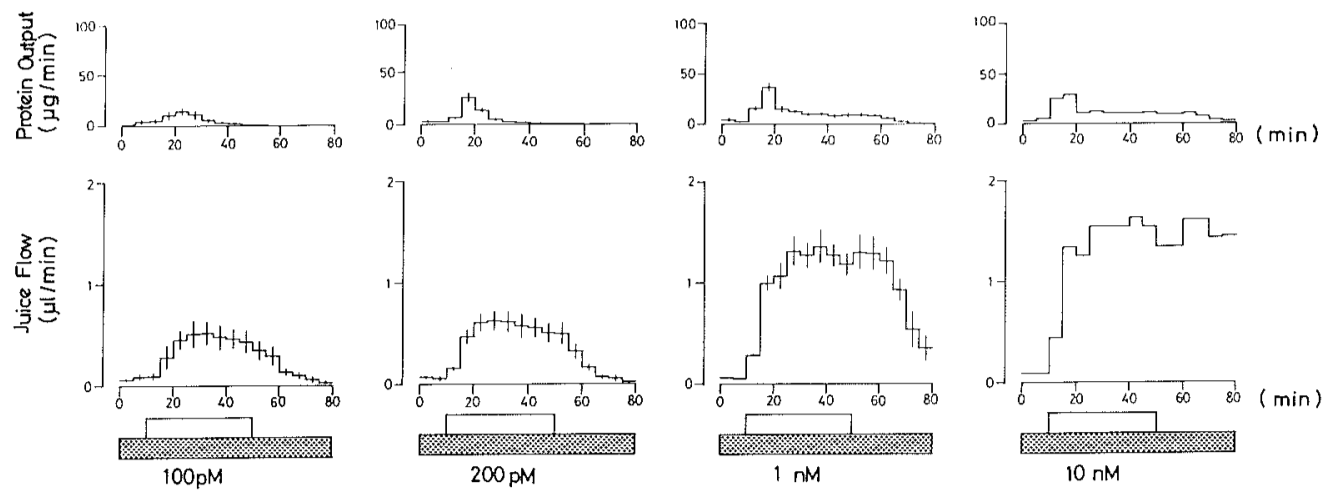

Fig. 2 Time course of changes in pancreatic protein output and juice flow during continuous stimulation of the isolated rat pancreas with $0.1,0.2,1$, and $10 \mathrm{nM}$ in a Ca ${ }^{2+}$-deficient environment $\left(\mathrm{CaCl}_{2}\right.$ was removed from the perfusing and the bathing solution). Each value represents the mean of four experiments. The open horizontal bar indicates the period of secretin stimulation.

and juice flow in the $\mathrm{Ca}^{2+}$-containing or $\mathrm{Ca}^{2+}$. deficient environment were plotted in Fig. 3. Larger protein output was obtained when a higher secretin concentration was used in the environment containing $2.5 \mathrm{mM} \mathrm{Ca}{ }^{2+}$, whereas the output remained very small even when a higher secretin concentration was used in the $\mathrm{Ca}^{2+}$-deficient environment. On the contrary, a dose-dependent increase in juice flow was obtained whether the extracellular solution contained $\mathrm{Ca}^{2+}$ or not. The response to a lower secretin concentration in the $\mathrm{Ca}^{2+}$-deficient environment was significantly smaller than that in the $\mathrm{Ca}^{2+}$-containing environment, but the difference between the responses in the $\mathrm{Ca}^{2+}$-deficient and $\mathrm{Ca}^{2+}$ containing environments to higher secretin concentration was not significant.

\section{$\mathrm{Ca}^{2+}$-dependent Secretory Responses to Forskolin}

It is commonly believed that the secretininduced secretory responses are exerted by increasing the intracellular concentration of cyclic AMP (3), which is also known to mediate the responses to forskolin (20). In the following experiments, we used $1 \mu \mathrm{M}$ forskolin, which was shown to induce pancreatic secretory responses comparable to those to $1 \mathrm{nM}$ secretin.

Continuous stimulation with $1 \mu \mathrm{M}$ forskolin induced sustaining increases in juice flow and protein output in the environment 

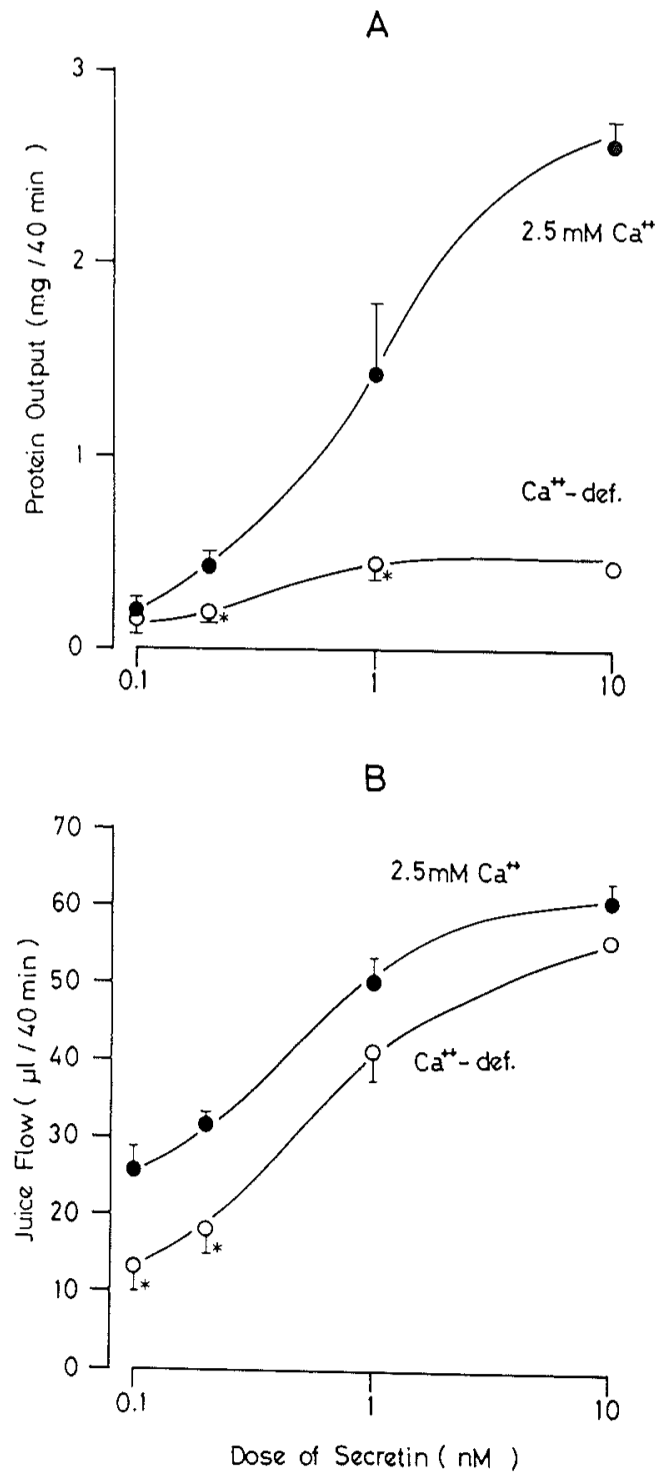

Fig. 3 Pancreatic protein output and juice flow in response to doses of secretin in a $\mathrm{Ca}^{2+}$-containing and $\mathrm{a} \mathrm{Ca}^{2+}$-deficient environment. The protein output and juice flow are the total amount in a sample collected during $40 \mathrm{~min}$ of stimulation with secretin. Each value shown by the filled circles ( $\bullet$ ) indicates the respective experiments carried out in a $\mathrm{Ca}^{2+}$-containing environment as in Fig. 1, and that shown by open circles $(0)$ indicates the mean value of corresponding experiments carried out in a $\mathrm{Ca}^{2+}$ - deficient environment as in Fig. 2. Asterisks $\left(^{*}\right)$ underneath the open circles represent significant $(P<0.05)$ difference between the values immediately above. containing $2.5 \mathrm{mM} \mathrm{Ca}^{2+}$ (Fig. 4). In the $\mathrm{Ca}^{2+}$ deficient environment, the stimulation induced only a small and transient increase in protein output, and a diminished but sustaining increase in juice flow (Fig. 4). The maximum plateau level of forskolin-induced juice flow in the $\mathrm{Ca}^{2+}$-deficient environment was about $1 / 4$ of that in the $\mathrm{Ca}^{2+}$-containing environment.

\section{$\mathrm{Ca}^{2+}$-dependent Secretory Responses to $d b c A M P$}

Since cyclic AMP is a possible intracellular messenger of secretin- and forskolin-induced secretory responses, the influence of extracellular $\mathrm{Ca}^{2+}$ on the secretory responses to dbcAMP, which is known to penetrate into a cell (6), was examined. dbcAMP $(100 \mu \mathrm{M})$ and $10 \mu \mathrm{M}$ IBMX were added to the perfusing solution. IBMX was used to prevent possible deterioration of dbcAMP. In a preliminary test, IBMX was found to be ineffective on the secretory responses.

Continuous stimulation with $100 \mu \mathrm{M}$ dbcAMP induced a very slow increase in protein output and juice flow (Fig. 5). In the $\mathrm{Ca}^{2+}$ deficient environment, the dbcAMP-induced protein output was significantly inhibited $(P<0.01)$, whereas the difference between dbcAMP-induced juice flow in the $\mathrm{Ca}^{2+}$-deficient and the $\mathrm{Ca}^{2+}$-containing environments was not significant.

\section{Change in Cyclic AMP Content Induced by Secretin and Forskolin}

As shown in Figs. 3 and 4, both secretin- and forskoplin-induced protein output were strongly inhibited in the $\mathrm{Ca}^{2+}$-deficient environment. The following experiments were carried out to examine the influence of extracellular $\mathrm{Ca}^{2+}$ on the secretagogue-induced change in cyclic AMP content of the pancreas.

Continuous stimulation with $1 \mathrm{nM}$ secretin gradually increased cyclic AMP content of the pancreas in the $\mathrm{Ca}^{2+}$-containing environment. In the $\mathrm{Ca}^{2+}$-deficient environment, the stimulation failed to increase cyclic AMP content (Fig. 6).

Continuous stimulation with $1 \mu \mathrm{M}$ forskolin significantly increased cyclic AMP content of the pancreas $40 \mathrm{~min}$ after starting the stimulation in the $\mathrm{Ca}^{2+}$-containing environment (Fig. 6). In the $\mathrm{Ca}^{2+}$-deficient environment, the stimulation failed to increase cyclic AMP 
A
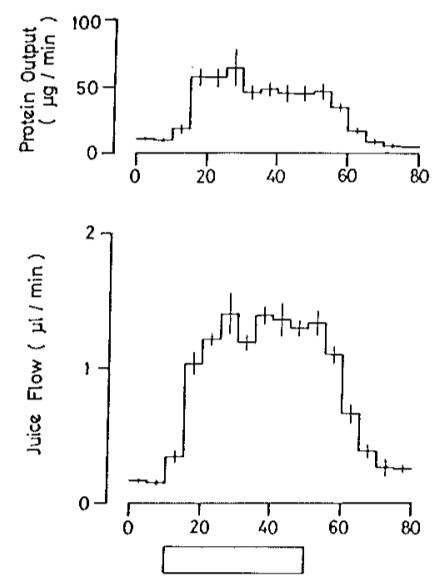

B
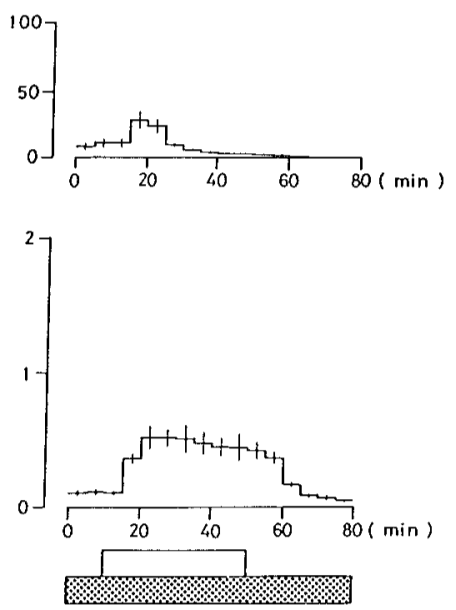

Fig. 4 Time course of changes in pancreatic protein output and juice flow during continuous stimulation of the isolated rat pancreas with $1 \mu \mathrm{M}$ forskolin in a $\mathrm{Ca}^{2+}$-containing and $\mathrm{Ca}^{2+}$-deficient environment. Each value represents the mean of four experiments. The horizontal open bar indicates the period of forskolin stimulation, and the shaded horizontal bar indicates the period of $\mathrm{Ca}^{2+}$ - removal from the perfusing and bathing solution.

content.

\section{DISCUSSION}

\section{Secretin-induced Secretory Responses}

It is commonly believed that secretin acts on the ductal tissue (terminal duct cells and centro-acinar cells) of the pancreas to induce juice flow and $\mathrm{NaHCO}_{3}$ secretion $(3,21)$, and that binding of secretin with secretin receptor activates adenylate cyclase, which in turn increases intracellular cyclic AMP.

The range of plasma secretin level before and after eating has not yet been estimated in the rat, but when estimated by radioimmunoassay, the plasma secretin level was found to be about $20 \mathrm{pM}$ when diluted $\mathrm{HCl}$ was infused into the duodenal lumen in the anesthetized $\operatorname{dog}(16)$. The secretin concentrations used in the present experiments ranged from $100 \mathrm{pM}$ to $10 \mathrm{nM}$, which may be in the range of the physiological and pharmacological concentration.

The present experiments demonstrated that in the isolated perfused rat pancreas, continuous stimulation with secretin (over the concentration range $0.1-10 \mathrm{nM}$ ) induced a dosedependent increase in juice flow as well as in protein output, and that the secretin-induced protein output was almost nullified when $\mathrm{Ca}^{2+}$ was removed from the perfusing and bathing solution. The protein output may be due to secretin-induced stimulus-secretion coupling in the pancreatic acinar cells, since zymogen granules can be detected morphologically in the acinar cells but not in the cells of ductal tissue. Secretin-induced pancreatic enzyme output was already demonstrated in the pancreas of rats (1). Secretin-specific receptors were demonstrated not only in the cells of the ductal tissue (4), but also in acinar cell (1). A commonly accepted view is that the binding of secretin with the receptors may activate adenylate cyclase (18) and the synthesis of cyclic AMP, and in turn, may induce extrusion of pancreatic enzyme proteins $(7,8,15)$. This view may be compatible with the following results in the present experiments: 1) continuous stimulation with $1 \mathrm{nM}$ secretin, and with $1 \mu \mathrm{M}$ forskolin, gradually increased cyclic AMP content of the whole pancreas (Fig. $6)$; 2) the stimulation induced sustaining secretory responses in isolated perfused rat pancreas (Figs. 1 and 4); and 3) dbcAMP per se caused secretory responses (Fig. 5).

\section{$\mathrm{Ca}^{2+}$-dependent Secretory Responses to Secretin}

The results that the removal of extracellular 
A
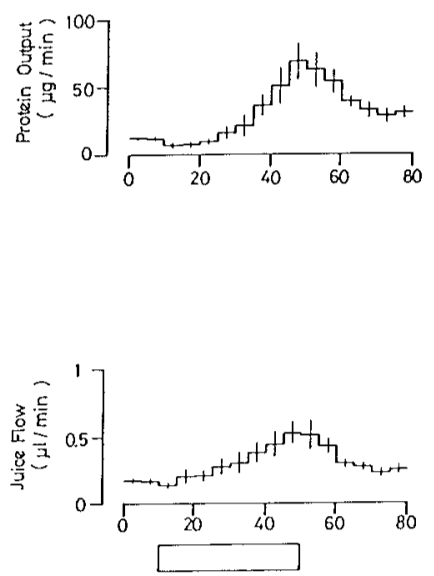

B
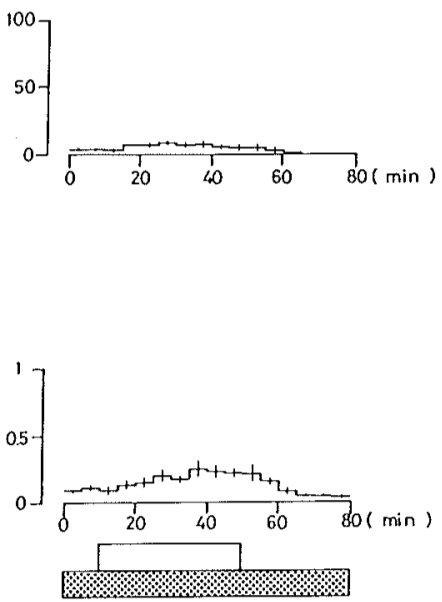

Fig. 5 Time courses of changes in pancreatic protein output and juice flow during continuous stimulation with $100 \mu \mathrm{M}$ dbcAMP in a $\mathrm{Ca}^{2+}$-containing and $\mathrm{a} \mathrm{Ca}^{2+}$-deficient environment. Each value represents the mean of four experiments. The open horizontal bar indicates the period of dbcAMP stimulation, and the shaded horizontal bar indicates the period of $\mathrm{Ca}^{2+}$ removal from the perfusing and the bathing solution.
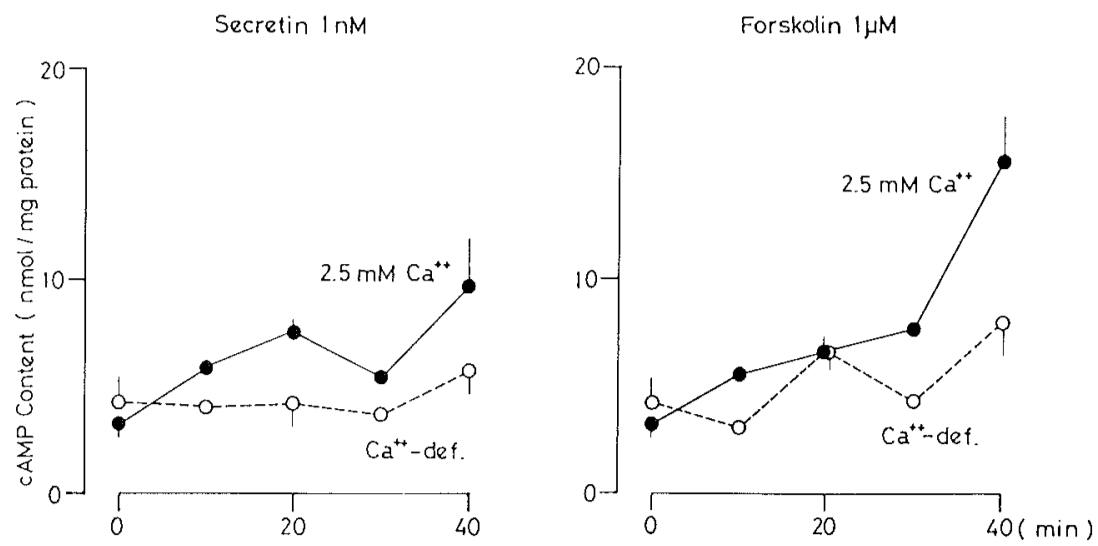

Fig. 6 Change in cyclic AMP content of the idolated pancreas perfused with $1 \mathrm{nM}$ secretin or $1 \mu \mathrm{M}$ forskolin in a $\mathrm{Ca}^{2+}$-containing or $\mathrm{Ca}^{2+}$-deficient environment. Each value represents the mean of four preparations.

$\mathrm{Ca}^{2+}$ almost completely abolished the secretory responses to secretin, forskolin, and dbcAMP resembles the results of previous experiments in which the removal of extracellular $\mathrm{Ca}^{2+}$ almost completely abolished the secretory responses to continuous stimulation with CCK at a physiological concentration (2$20 \mathrm{pM} ; 11,13,22)$. The similarity between the present and previous results led us to conclude that the influx of extracellular $\mathrm{Ca}^{2+}$ is the dominant source of the increase in cytoplasmic $\mathrm{Ca}^{2+}$ concentration when the pancreatic acinar cell is stimulated with secretin at a pharmacological concentration and with $\mathrm{CCK}$ at a physiological concentration.

The question now arises as to which of these two intracellular messengers, $\mathrm{Ca}^{2+}$ or cyclic AMP, plays a major role in the stimulussecretion coupling activated by secretin? For the answer, at least two views may be proposed. 
The first view is that the final event in the coupling may be $\left[\mathrm{Ca}^{2+}\right]_{i}$-induced exocytosis of the zymogen granules, and the final event may be potentiated by the increase in cyclic AMP. The second view is that cyclic AMP may trigger the process of exocytosis, and extracellular $\mathrm{Ca}^{2+}$ may play a role as an activator of adenylate cyclase in the plasma membrane of acinar cells. A support for the second view is the fact that lowering extracellular $\mathrm{Ca}^{2+}$ is known to inhibit the activity of adenylate cyclase in many types of cells (17). The second view may harmonize with the present result that the removal of $\mathrm{Ca}^{2+}$ nullified secretin- and forskolin-induced increase in cyclic AMP content (Fig. 6).

However, the second view does not agree with the present result that dbcAMP-induced protein output was also markedly diminished in the $\mathrm{Ca}^{2+}$-deficient environment. This result can be explained by the first view. If secretin can induce increases in both cyclic AMP and $\mathrm{Ca}^{2+}$ influx in the acinar cell, then the synarchic interaction between these two intracellular messengers may greatly potentiate $\left[\mathrm{Ca}^{2+}\right]_{\mathrm{i}}$-dependent exocytosis of zymogen granules.

In the course of preparing this paper, the following two papers appeared and suggested that the first view may be more valid. Trimble et al. (25) demonstrated that, besides cyclic AMP, other second messengers such as inositol trisphosphate, diacylglycerol, and intracellular $\mathrm{Ca}^{2+}$ are increased by secretin in isolated rat acini. They proposed that these four messengers must be taken into account when considering the mechanism(s) by which secretin promotes amylase output from pancreatic acinar cells. Shinozaki et al. (23) showed that in the dispersed rat pancreatic acini, the amylase released by secretin, forskolin, and dbcAMP was inhibited by W-7, a calmodulin antagonist, and by the removal of $\mathrm{Ca}^{2+}$ from the medium. They postulated that the first phase of the secretin-induced amylase release is interacted strongly by $\mathrm{Ca}^{2+}$-calmodulin complex, and the second phase of secretin-induced amylase release and forskolin- and dbcAMPinduced amylase release is interacted by both of the cyclic AMP passage and intracellular $\mathrm{Ca}^{2+}$ pool. The results obtained by Shinozaki et al. (23) however, are different from ours in the following aspects. 1) They used dispersed acini, and stimulated by secretagogues at much higher concentrations (500 nM secretin, $50 \mu \mathrm{M}$ forskolin, and $2 \mathrm{mM}$ dbcAMP), which are 5,000, 50, and 10 times higher than concentrations of the respective secretagogues we used. Previous studies in our laboratory provided evidence that the influence of extracellular $\mathrm{Ca}^{2+}$ and the cellular mechanism of stimulus-secretion coupling in the acinar cell are not identical among the secretory responses to physiological, pharmacological, and toxic concentrations of CCK $(11,22)$. Such dose dependency of extracellular $\mathrm{Ca}^{2+}$ and of the cellular mechanism may also be recognized in the responses to secretin. In fact, amylase released by $500 \mathrm{nM}$ secretin in the dispersed acini showed a biphasic secretory pattern, which resembled the pattern induced by CCK stimulation at the pharmacological and toxic concentrations in the perfused pancreas $(11,13,22) .2)$ The secretory response of dispersed acini was much smaller than that of the perfused pancreas. Amylase released by $500 \mathrm{nM}$ secretin in dispersed acini was about 2 times larger than the resting level, whereas protein released by $0.1 \mathrm{nM}$ secretin in the perfused pancreas was 6 times larger than the resting level. 3) The present study demonstrated the effects of secretin on both protein output and juice flow, and the unique influence of extracellular $\mathrm{Ca}^{2+}$ on secretininduced protein output. The $\mathrm{Ca}^{2+}$-resistant component of secretin-induced juice flow may possibly be due to the secretory response of the ductal tissue (4).

The investigation was supported by a grant-in-aid of Scientific Research (No. 61440025) from the Ministry of Education, Science and Culture, Japan.

Received for publication 28 May 1987; and in revised form 15 June 1987

\section{REFERENCES}

1. Bissonnette B. M., Collen M. J., Adachi H., JENSEN R. T. and GARDNER J. D. (1984) Receptors for vasoactive intestinal peptide and secretin on rat pancreatic acini. Amer. J. Physiol. 246, G710-G717

2. Brown B. L., Albano J. D. M., Ekins R. P. and Sgherzi A. M. (1971) A simple and sensitive saturation assay method for the measurement of adenosine $3^{\prime}: 5^{\prime}$-cyclic monophosphate. Biochem. $J .121,561-562$

3. CASE R. M. (1974) The role of calcium and cyclic AMP in pancreatic secretory processes. In Secretory Mechanisms of Exocrine Glands (ed. Thorn N. A. and Petersen O. H.) Academic Press, New York, pp. 344-354

4. CASE R. M. (1978) Synthesis, intracellular transport and discharge of exportable proteins in 
the pancreatic acinar cell and other cells. Biol. Rev. 53, 211-354

5. Case R. M., Harper A. A. and Scratcherd T. (1969) The secretion of electrolytes and enzymes by the pancreas of the anaethetized cat. J. Physiol. 201, 335-348

6. CASE R. M. and SCratcherd T. (1972) The actions of dibutyryl cyclic adenosine $3^{\prime}, 5^{\prime}$ monophosphate and methyl xanthines on pancreatic exocrine secretion. J. Physiol. 223, 649667

7. De Pont J. J. H. H. M., Luyben D. and Bonting S. L. (1979) Rat pancreas adenylate cyclase. VI. Role of the enzyme in secretin stimulated enzyme secretion. Biochim. Biophpys. Acta 584, 33-42

8. Deschodt-Lanckman M., Robberecht P., De NeEF P., LABRie F. and Christophe J. (1975) In vitro interactions of gastrointestinal hormones on cyclic adenosine $3^{\prime}: 5^{\prime}$-monophosphate levels and amylase output in the rat pancreas. Gastroenterology 68, 318-325

9. DockRay G. J. (1972) The action of secretin, cholecystokinin-pancreozymin and caerulein on pancreatic secretion in the rat. J. Physiol. 225, 679-692

10. Heatley N. G. (1968) The assay of pancreozymin, and of secretin and pancreozymin simultaneously, in the rat. J. Endocrinol. 42, 549-557

11. Kanno T. and Matsumoto T. (1986) Influence of extracellular $\left[\mathrm{Ca}^{2+}\right]$ on secretory and redox responses to CCK-8 in perfused rat pancreas. Amer. J. Physiol. 251, C10-C16

12. Kanno T. and Nishimura O. (1976) Stimulussecretion coupling in pancreatic acinar cells: inhibitory effects of calcium removal and manganese addition on pancreozymin-induced amylase release. J. Physiol. 257, 309-324

13. Kanno T., Shibuya I. and Asada N. (1983) The role of extracellular calcium and other ions in the secretory responses of the exocrine pancreas to cholecystokinin. Biomedical Res. 4, 295-302

14. Kanno T., Suga T. and Yamamoto M. (1976) Effects of oxygen supply on electrical and secretory responses of humorally stimulated acinar cells in isolated rat pancreas. Jap. J. Physiol. 26,
$101-115$

15. Kempen H. J. M., De Pont J. J. H. H. M. and BonTING S. L. (1974) Rat pancreas adenylate cyclase. II. Inactivation and protection of its hormone receptor sites. Biochim. Biophys. Acta 370, 573-584

16. Kim M. S., LeE K. Y. and CheY W. Y. (1979) Plasma secretin concentrations in fasting and postprandial states in dog. Amer. J. Physiol. 236, E539-E544

17. Rasmussen H. (1981) Calcium and cAMP as Synarchic Messengers. A Wiley-Interscience Publication, New York/Chichester/Brisbane/ Toronto/Singapore

18. Rutten W. J., De Pont J. J. H. H. M. and BontING S. L. (1972) Adenylate cyclase in the rat pancreas properties and stimulation by hormones. Biochim. Biophys. Acta 274, 201-213

19. Schulz I., Yamagata A. and Weske M. (1969) Micropuncture studies on the pancreas of the rabbit. Pflugers Arch. ges. Physiol. 308, 277-290

20. Seamon K. B., Padgett W. and Daly J. W. (1981) Forskolin: Unique diterpene activator of adenylate cyclase in membranes and in intact cells. Proc. Natl. Acad. Sci. USA 78, 3363-3367

21. Sewell W. A. and Young J. A. (1975) Secretion of electrolytes by the pancreas of the anaesthetized rat. J. Physiol. 252, 379-396

22. Shibuya I. and Kanno T. (1985) Calciumdependent secretory and redox response to CCK-8 in isolated perfused rat pancreas. Amer. J. Physiol. 248, C228-C234

23. Shinozaki H., Kimura T., Imamura K. and IBAYASHI H. (1986) Participation of $\mathrm{Ca}^{2+}$ and calmodulin in rat pancreatic enzyme secretion induced by secretin, forskolin, and dibutyryl cyclic AMP. Jap. J. Physiol. 36, 1079-1092

24. Swanson C. H. and Solomon A. K. (1973) A micropuncture investigation of the whole tissue mechanism of electrolyte secretion by the in vitro rabbit pancreas. J. Gen. Physiol. 62, 407-429

25. Trimble E. R., Bruzzone R., Biden T. J. and FARESE R. V. (1986) Secretin induces rapid increases in inositol trisphosphate, cytosolic $\mathrm{Ca}^{2+}$ and diacylglycerol as well as cyclic AMP in rat pancreatic acini. Biochem. J. 239, 257-261 